JURNAL RISET MAHASISWA AKUNTANSI (JRMA)

Volume IX, No. 2, Tahun 2021

e-ISSN : 2715 - 7016

\title{
Strategi Going Concern Pedagang Mlijo Pada Masa Pandemi
}

\author{
Supami Wahyu Setiyowati ${ }^{1}$, Munawar ${ }^{2}$, Djalaludin ${ }^{3}$ \\ 1,2,3 Universitas Islam Negeri Maulana Malik Ibrahim Malang, Indonesia
}

\section{Corresponding Author}

Nama Penulis: Supami Wahyu Setiyowati

Email: setiyosarip26@gmail.com

\begin{abstract}
Abstrak
Tujuan dari penelitian ini adalah untuk mengetahui penerapan prinsip going concern dan kendala yang dialami oleh Mlijo atau pedagang pedang keliling selama masa covid 19. Lokasi penelitian berada di Kelurahan Cemorokandang, Kecamatan Kedungkandang, Kota Malang. Metode penelitian yang digunakan adalah pendekatan kualitatif dengan pendekatan deskriptif. Informan yang dipilih adalah 4 pedagang Mlijo. Teknik pengumpulan data yang digunakan adalah reduksi data, pemaparan data, dan penarikan kesimpulan data. Hasil kajian menunjukkan bahwa kondisi pedagang Mlijo di masa pandemi Covid 19 sudah menerapkan prinsip going concern meski perkembangannya kecil. Pedagang Mlijo menerapkan prinsip going concern dalam usaha dagang dan ekonomi keluarga. Strategi kelangsungan bisnis perdagangan dengan mengutamakan barang yang dipesan oleh pembeli dan menambahkan barang yang sedang tren atau musiman. Pengelolaan ekonomi keluarga meliputi pengelolaan keuangan keluarga dengan mengutamakan kebutuhan yang dianggap penting agar pengeluaran tidak melebihi pendapatan. Pengeluaran keluarga meliputi alokasi keuangan untuk kebutuhan makan sehari-hari, biaya pendidikan anak, pembayaran cicilan pinjaman, dan tabungan.
\end{abstract}

\section{Kata kunci : Going Concern, Pedangang Mlijo}

\begin{abstract}
The purpose of this study was to determine the implementation of the going concern principle and the obstacles experienced by Mlijo or mobile sword traders during the covid 19 periods. The research site was in Cemorokandang Village, Kedungkandang District, Malang City. The research method used is a qualitative approach with a descriptive approach. The informants selected were 4 Mlijo traders. The data collection techniques used were data reduction, data exposure, and data conclusions. The results of the study show that the condition of Mlijo traders during the Covid 19 pandemic has implemented the going concern principle even though the development is small. Mlijo traders apply the going concern principle in trading businesses and the family economy. A trading business going concern strategy by prioritizing goods ordered by buyers and adding items that are trending or seasonal. Management of the family economy includes managing family finances by prioritizing needs that are considered important so that expenses do not exceed income. Family expenses include financial allocations for daily food needs, children's education costs, and paying loan installments.
\end{abstract}

Keywords: Going concern, The Mlijo trader 


\section{PENDAHULUAN}

Salah satu kondisi yang tidak terduga adalah terjadinya bencana dan wabah penyakit. Pandemi Covid19 yang melanda dunia tidak terkecuali Indonesia (sejak Februari 2020) membawa dampak yang cukup berat bagi masyarakat, termasuk para pelaku usaha mikro. Usaha mikro yang sebagian besar mengandalkan pendapatan sehari-hari merupakan salah satu jenis usaha yang paling rentan terhadap kebangkrutan karena tidak memiliki cadangan aset yang dapat menopang usahanya dalam menghadapi masa-masa sulit.

Sektor informal yang paling banyak diminati oleh masyarakat Indonesia pada umumnya dan kota Malang pada khususnya adalah pedagang. Beberapa jenis pekerjaan yang termasuk di dalam sektor informal, salah satunya adalah pedagang kaki lima, seperti warung nasi, penjual rokok, penjual koran dan majalah, penjual makanan kecil dan minuman, dan pedagang Mlijo. Pedagang tersebut merupakan pelaku usaha mikro yang keberadaannya sangat dibutuhkan oleh masyarakat di beberapa tempat.

Pedagang Mlijo menjadi stimulan yang muncul dan berkembangnya usaha-usaha mikro dengan menjadi penyedia barang-barang pokok yang dijajakan masyarakat. Produsen kebutuhan sehari - hari, mulai banyak yang memanfaatkan pedagang mlijo sebagai tenaga pemasar yang dapat secara langsung menyentuh konsumen. Saat ini sektor informal berkembang pesat di Indonesia, khususnya di kota-kota besar termasuk Malang. Hal itu disebabkan sektor informal memberi ruang kepada masyarakat yang tidak memiliki skill dalam sektor ekonomi formal. Karakteristik sektor informal yaitu bentuknya tidak terorganisir, kebanyakan usaha sendiri, cara kerja tidak teratur, biaya dari diri sendiri atau sumber tidak resmi, dapatlah diketahui berapa banyaknya jumlah anggota masyarakat memilih tipe usaha ini, karena mudah dijadikan sebagai lapangan kerja bagi masyarakat strata ekonomi rendah yang banyak terdapat di negara kita terutama pada kota besar maupun kecil.

Kota Malang sebagai salah satu kota terbesar di Jawa Timur dan menjadi tempat yang sangat potensial bagi sektor informal untuk mencari rezeki terutama bagi pedagang Mlijo. Untuk mendapatkan gambaran secara mudah tentang jumlah dan kepadatan penduduk masing-masing Kelurahan di Kecamatan Kedungkandang dapat dilihat pada tampilan grafik sebagai berikut:

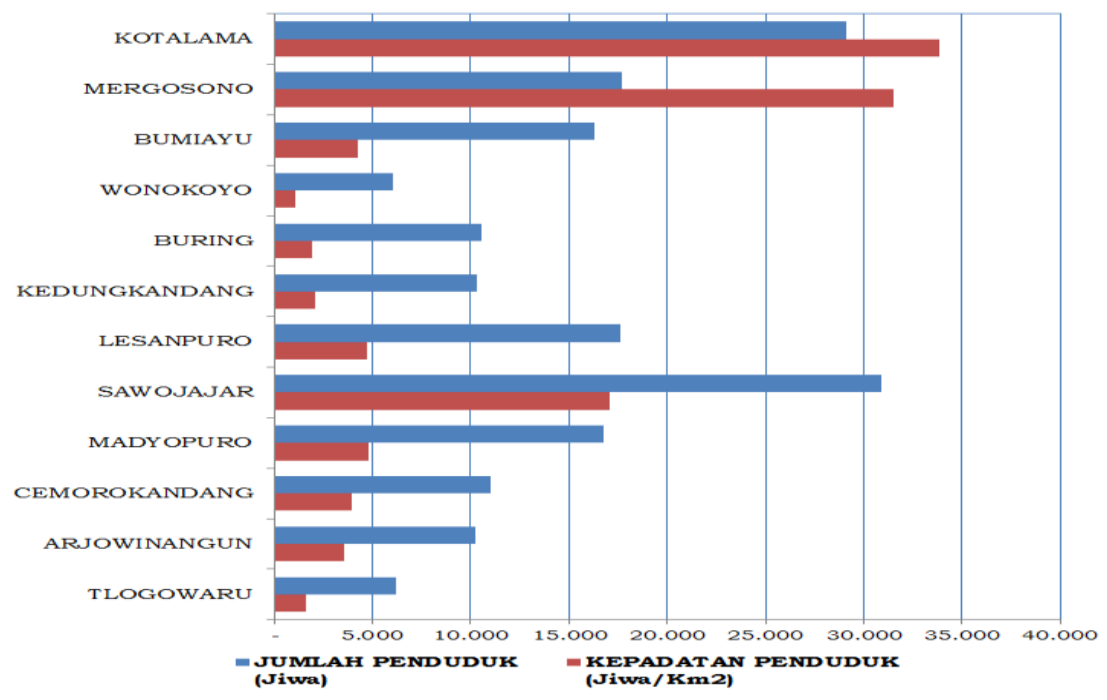


Kelurahan yang dijadikan fokus penelitian ini ialah kelurahan Cemorokandang. Kelurahan Cemorokandang merupakan kelurahan yang terletak di wilayah Kecamatan Kedungkandang, Kota Malang. Kelurahan ini terdiri dari 11 RW (Rukun Warga) dan 61 RT (Rukun Tetangga). Jumlah penduduk kelurahan Kedungkandang adalah 12.113 jiwa. Potensi yang sangat besar bagi pedang Mlijo untuk menjual sembako kepada masyarakat.

Banyak cara dan upaya yang dilakukan para pedagang Mlijo dalam mendukung kondisi sosial ekonominya di tengah derasnya arus pembangunan kota yang setiap hari selalu menuntut persaingan dan kerja keras dari seluruh elemen masyarakat. Komunikasi dengan sesama pedagang Mlijo belum tentu baik. Hal ini disebabkan persaingan dan ambisi untuk mendapatkan keuntungan. Dengan kondisi yang serba kekurangan, dan tidak didukung oleh aset produksi yang memadai, yang bisa dicapai oleh keluarga miskin saat ini adalah bagaimana mereka bisa bertahan, dan berusaha semaksimal mungkin agar tidak tergerus oleh pusaran krisis yang akan membuat mereka semakin sengsara. Bagi keluarga miskin di kota, sebenarnya mereka tidak pernah berani berharap bisa melakukan mobilitas vertikal dengan cepat atau menjadi orang yang mapan tanpa harus dibayangi tagihan utang. Bagi orang miskin, selama mereka bisa bertahan hidup dan tidak menjadi miskin, sebenarnya itu adalah kemewahan tersendiri.

Di kalangan penduduk miskin di kota, utang boleh dikatakan adalah hal yang lazim dan paling populer. Mekanisme gali lubang tutup lubang bagi penduduk miskin adalah sesuatu hal yang biasa dilakukan, karena memang hanya dengan cara itu mereka dapat memperpanjang nafas untuk melangsungkan kehidupannya. Berbeda dengan keluarga yang secara ekonomi mapan dan biasanya memiliki tabungan untuk memenuhi kebutuhan yang sifatnya mendadak. Yang namanya keluarga miskin di kota rata-rata kehidupan sehari- harinya sangat rentan, tidak memiliki tiang penyangga atau tabungan yang dapat dimanfaatkan untuk memenuhi kebutuhan yang sifatnya mendadak, sehingga ketika kebutuhan itu sudah ada di depan mata, maka tidak ada cara lain yang dapat dilakukan kecuali utang ke sana-sini, termasuk utang ke rentenir yang acapkali meminta beban bunga yang tinggi.

Bagi penduduk miskin, keberadaan kelompok dan kohesi sosial yang kuat, merupakan sesuatu yang fungsional semacam garansi sosial untuk mendukung kelangsungan penduduk miskin, terutama ketika mereka menghadapi masalah. Dengan modal yang terbatas atau bahkan sama sekali tidak ada, dan juga karena koneksi yang serba terbatas, disadari responden bahwa ruang gerak mereka untuk berkembang dan mengembangkan usahanya menjadi sangat sempit. Di tengah kondisi perekonomian yang tak kunjung membaik, memang tidak mudah bagi penduduk miskin di kota untuk mempertahankan apalagi mengembangkan usahanya. justru usaha yang mereka tekuni collapse akibat daya beli masyarakat yang menurun drastis, sementara biaya produksi yang dikeluarkan justru naik karena efek domino dari krisis ekonomi pada masa pademi covid 19.

Hasil penelitian terkait pembahasan going concern yakni penelitian dari (Paranoan et al., 2021), hasil penelitian ini menunjukkan bahwa Sambu 'Barumbun memiliki konsep going concern yang digunakan pada saat Kegiatan adat juga digunakan sebagai sumber pendapatan bagi Mamasa masyarakat (Purwanti, 2018), Secara keseluruhan, hasil ini menunjukkan bahwa pengumuman short run going concern berdasarkan informasi pribadi dan fundamental, meskipun kendala perdagangan mencegah mereka sepenuhnya menyita keparahan informasi negatif dalam jangka pendek, memberikan penjelasan parsial untuk pergerakan harga jangka panjang pasca- akan perhatian. Beberapa penelitian lain terkait going concern ialah (Yunus, 2011) dan (Irwan, 2015), menjelaskan bahwa 
strategi paguyuban dan strategi dari pedagang asongan itu sendiri. Strategi dari paguyuban dilakukan melalui kegiatan seperti pertemuan rutin, selametan, halal bihalal, refreshing, dan kerjasama dengan pihak luar sedangkan strategi dari pedagang dilakukan dengan cara menaati peraturan, menjaga sopan santun, komunikasi yang baik, memaksimalkan jam kerja, sikap pantang menyerah, dan memanfaatkan media sosial.

Atas beberapa penelitian tersebut memberikan hasil bahwa selama ini belum banyak studi yang mengkaji strategi going concern pedagang Mlijo di kelurahan Cemorokandang, padahal fenomena pedagang Mlijo semakin marak dengan bertambahnya pedagang Mlijo . Berdasarkan pemikiran tersebut maka penulis ingin mengetahui tentang keberadaan pedagang Mlijo khususnya di keluruhan Cemorokandang. Untuk itu penulis mengangkat judul Strategi going concern Komunitas Pedagang mlijo di kelurahan Cemorokandang dimasa pademi covid 19.

\section{TINJAUAN PUSTAKA}

Going Concern

Going concern menurut SPAP adalah suatu keadaan di mana perusahaan dapat tetap beroperasi dalam jangka waktu ke depan, dimana hal ini dipengaruhi oleh keadaan financial dan non financial. Kegagalan mempertahankan going concern dapat mengancam setiap perusahaan, terutama diakibatkan oleh manajemen yang buruk, kecurangan ekonomis dan perubahan kondisi ekonomi makro seperti merosotnya nilai tukar mata uang dan meningkatnya inflasi secara tajam akibat tingginya tingkat suku bunga (12SPAP, PSA 30 SA341.1, n.d.).

Kelangsungan hidup dan kegagalan perusahaan adalah dua sisi yang saling bertolak belakang, ibarat sisi depan dan belakang sekeping uang logam. Asumsi going concern digunakan apabila suatu perusahaan dapat mempertahankan kelangsungan hidupnya. Namun, kemungkinan perusahaan mengalami kegagalan dalam mempertahankan kelangsungan hidupnya selalu ada, apabila dengan kondisi krisis ekonomi dan keuangan (Purba, 2009). Opini terkait going concern mengisyaratkan bahwa sebuah perusahaan dalam kondisi baik dan dapat menjalankan usahanya setiap periodenya (tidak ada indikasi akan mengalami kebangkrutan (Ginting \& Tarihoran, 2017).

\section{METODE}

Metode yang digunakan dalam penelitian ini adalah metode penelitian kualitatif dengan pendekatan deskriptif. Dalam penelitian ini dipilih 4 orang informan pedagang Mlijo di kelurahan cemorokandang. Teknik pengumpulan data yang digunakan adalah observasi, wawancara, serta dokumentasi. Teknik analisis data yang digunakan yaitu reduksi data, pemaparan data, dan simpulan melalui hasil penelitian dan verifikasi data.

Tabel 1 Data Informan

\begin{tabular}{|c|l|l|}
\hline NO & \multicolumn{1}{|c|}{ Nama Etnis } \\
\hline 1 & Ibu Romlah & Madura \\
\hline 2 & Bapak Arif & Jawa \\
\hline 3 & Bapak Muhammad & Madura \\
\hline 4 & Ibu Ruroh & Jawa \\
\hline
\end{tabular}




\section{PEMBAHASAN}

\section{Latar belakang kehidupan pedagang Mlijo}

Latar belakang kehidupan sosial para pedagang Mlijo di kelurahan Cemorokandang kecamatan kedungkandang kota Malang berasal dari kelurahan cemorokandang dan dari desa sekitar kelurahan cemorokandang. Tujuan pedagang Mlijo yang berasal dari luar kelurahan Cemorokandang hanya berd agang dan tidak menetap di kelurahan Cemorokandang. Meskipun disini terdapat dua golongan pedagang Mlijo, yakni penduduk asli dan pendatang, namun kehidupan diantara mereka menunjukkan adanya sikap yang damai dan rukun. Mereka dapat berdagang dengan aman dan bebas tanpa ada tekanan dari pihak lain. Bahkan hal-hal positif, seperti kebiasaan-kebiasaan masyarakat setempat yang menghargai orang lain tetap terpelihara dan di transformasikan dalam kehidupan para pedagang mlijo baik dari penduduk asli maupun pendatang yang ikut berdagang.

Dari segi etnis, pedagang mlijo di kelurahan Cemorokandang pada umumnya hanya etnis Jawa dan Madura. Kebanyakan yang menguasai perdagangan Mlijo di kelurahan Cemorokandang adalah etnis Madura tersebut. Meski begitu hubungan sosial ekonomi mereka tidak nampak adanya diskriminasi sehingga tidak ada sentimen kelompok atau sentiment etnis yang mengemuka. Seperti yang dikatakan oleh bapak Junjung Ketua RT 02 : “Kalau soal hubungan pedagang kayaknya biasabiasa aja nya. Tidak ada diskriminasi atau pertentangan misalnya agama, suku, bahasa. Kalau sendirisendiri orang itu ya biasanya itu, namanya juga orang berdagang." (4/08/2020). Dalam melakukan hubungan dagangnya melalui hubungan spontan saja ketika melakukan aktivitas dagang di kelurahan Cemorokandang.

Tingkat pendidikan yang dimiliki oleh komunitas pedagang Mlijo di kelurahan Cemorokandang merupakan salah satu faktor penyebab atau pendorong dalam memilih dan melakukan pekerjaan sebagai pedagang Mlijo, disamping faktor lainnya. Umumnya para pedagang mlijo memiliki tingkat pendidikan yang rendah. Sebagian besar dari mereka hanya mengenyam pendidikan di bangku Sekolah Dasar saja, bahkan ada sebagian dari mereka yang tidak mendapatkan pendidikan formal sama sekali. Dengan pendidikan yang rendah ini sangat mempengaruhi mereka dalam memilih pekerjaan, yaitu pekerjaan yang bisa terjangkau tanpa memperhatikan pendidikan apa yang telah dicapai. Salah satu pekerjaan tersebut adalah sebagai pedagang Mlijo. Pada kenyataanya didalam menjalankan pekerjaan mereka tidak membutuhkan jenjang pendidikan tertentu. Hal inilah yang membuat mereka merasa cocok dan menikmati pekerjaannya tersebut. Bagi mereka yang terpenting adalah kemauan dan kemampuan dalam menjalaninya, sebagai usaha untuk mencapai tujuan dari pekerjaan tersebut.

Pernyataan ini diungkapkan oleh bapak Arif menyatakan tentang pendidikannya dalam hubungannya dengan pekerjaan yang dijalaninya, sebagai berikut: "Saya sekolah hanya sampai tamat SD, bu , karena tidak bisa melanjutkan sekolah ke SMP karena salah pergaulan dengan anak anak yang suka minum minuman keras, makanya orang tua saya menyuruh menjadi pedagang Mlijo. Selain itu modal untuk berdagang Mlijo modalnya awalnya kecil. Makanya aku kerja sebagai pedagang Mlijo." (5/09/2020). Berdasarkan pernyataan tersebut dapat disimpulkan bahwa pemilihan mata pencaharian atau pekerjaan sebagai pedagang Mlijo merupakan bentuk perlakuan yang berdasarkan pada pertimbangan kesesuaian atas tingkat pendidikan yang rendah dan jenis pekerjaan bisa dimasuki serta tidak membutuhkan modal yang besar tetapi hanya membutuhkan kemampuan untuk menjalaninya saja. 
Semakin banyaknya pasar modern, menyebabkan banyak diantara pedagang pasar tradisional beralih profesi menjadi pedagang Mlijo yang masuk ke kelurahan Ccemorokandang. Seperti salah penjelasan informan Ibu Romlah berikut: “Dulu saya penjual di pasar Tumpang tetapi karena persaingan semakin ketat dan masa pandemic covid 19 maka saya berhenti berjualan di pasar, saya memilih berjualan keliling dan semakin dekat dari rumah warga jadi warga tidak kesulitan lagi mencari makanan. Makanya sekarang, saya menjadi pedagang Mlijo diwilayah kelurahan Cemorokandang." (8/08/2020).

Hal tersebut merupakan konsekuensi dari terjadinya krisis ekonomi yang disebabkan pandemic covid 19. Hal ini menyebabkan anak-anak potensial terpuruk dalam kondisi hubungan kerja yang merugikan. Sektor informal di perkotaan merupakan kelompok masyarakat yang cukup rentan terkena imbas dari berbagai kebijakan. Dalam segi ekonomi para pedagang Mlijo. Berbagai jenis aktivitas manusia tentunya mengharapkan imbalan, apalagi yang bernilai ekonomi tentunya. Imbalan yang dimaksud adalah pendapatan yang diperoleh pedagang Mlijo dalam bentuk materi (uang). Tentang kecukupan ekonomi dari hasil berdagang, pedagang mMijo menyesuaikan kebutuhannya semua dengan hasil yang didapat. Bisa saja terkadang kekurangan. Walaupun dengan untung yang kecil, pedagang Mlijo tetap berusaha untuk memenuhi kebutuhannya. Pedagang mlijo yang sudah berkeluarga, mau tidak mau harus dengan giat dan sabar menekuni pekerjaannya sebagai pedagang Mlijo untuk bisa bertahan hidup. Hal ini sesuai dengan apa yang disampaikan oleh (Purwanti, n.d.), yang mengatakan bahwa strategi yang baik digunakan agar lepas dari kemiskinan atau mampu bertahan hidup adalah dengan menggunakan strategi kesabaran, dimana kesabaran sangat dibutuhkan dalam menjalankan kelangsungan hidup seseorang, kesabaran juga sangat diperlukan dalam melakukan langkah-langkah untuk merubah semua potensi kehidupan menjadi lebih baik lagi. Dari para pedagang yang berhasil diwawancarai, pedagang Mlijo menyenangi profesinya saat ini. Antara lain karena tidak harus bekerja pada orang (tunduk pada bos) sehingga kebebasan ini menjadi daya tarik sendiri bagi pedagang mlijo. Pedagang mlijo mendagangkan kebutuhan pokok contohnya sayur, ikan ,daging, ayam, dan aneka bumbu. Pedagang Mlijo bekerja keras dari pagi hingga sore hari hanya untuk mendapatkan uang. Pendapatan yang pedagang Mlijo diperoleh juga tidak menentu, dalam per harinya. Seperti yang diungkapkan oleh informan bu Romlah berikut ini: "Pendapatan saya sebagai pedagang Mlijo yang menjual sembako, cukup untuk memenuhi kebutuhan keluarga. Saya juga masih bisa menabung meskipun jumlahnya tidak banyak." (08/08/2020)

Aktivitas informal tersebut merupakan cara melakukan sesuatu yang ditandai dengan akan ada banyak kalangan atau komunitas/masyarakat yang bisa terhidupi oleh sektor informal. Dengan kata lain, perputaran modal di sektor informal, jika diasumsikan sama dengan sektor formal, sesungguhnya akan mampu menghidupi jauh lebih banyak keluarga Indonesia. Hal di atas sesuai dengan yang disampaikan oleh (Suparlan, 1984) yang menyatakan bahwa yang termasuk penduduk miskin bukan hanya kaum migran yang berasal dari desa, tetapi tidak sedikit yang menderita kemiskinan di kota adalah penduduk asli setempat yang sejak awal sebelum kota berkembang sudah tergolong miskin berpendidikan rendah dan tidak memiliki keahlian yang berguna dalam kegiatan industri, sehingga mereka tersingkir dari kegiatan perekonomian perkotaan karena ketidakmampuan mereka turut berpartisipasi dan memanfaatkannya. 


\section{Strategi Going Concern Pedagang Mlijo}

Strategi going concern pada komunitas pedagang Mlijo di kelurahan Cemorokandang dalam menjalankan usahanya dengan cara membeli barang barang sesuai pesanan konsumen dan yang menjadi tren saat ini untuk dijual kembali. Atau istilahnya kulakan barang yang sesuai kebutuhan konsumen. Sdangkan going concern kelangsungan perekonomian keluarga dapat dijelaskan sebagai berikut; Adanya skala prioritas kebutuhan yang penting serta mengelola agar pengeluaran tidak melebihi pemasukan. Hal ini merupakan bagian dari manajemen keluarga yang diterapkan oleh pedagang Mlijo; Adanya pendistribusian alokasi keuangan untuk pendidikan, makan sehari-hari dan lainnya. Dalam hal ini sudah ada alokasi yang jelas untuk memenuhi kebutuhan pendidikan bagi anakanak, keperluan belanja untuk memenuhi kebutuhan makan sehari-hari, pemenuhan kebutuhan pembayaran fasilitas listrik, acara tak terduga seperti sumbangan bila tetangga hajatan; Meminjam (berhutang) pada teman, tetangga dan lainnya. Kondisi para pedagang Mlijo; Menabung. Sebagian penghasilan dari berdagang Mlijo ditabung untuk keperluan pendidikan anak dan lain-lain. Bahkan terkadang untuk keperluan tak terduga; Mengganti jenis dagangan sesuai dengan periode musim buah-buahan. Hal ini berlaku pada pedagang Mlijo yang berjualan sembako dan buah- buahan. Sehingga ketika musim buah salak maka pedagang Mlijo akan menambah salak, demikian pula ketika musim buah mangga maka pedagang tersebut akan menjual manga dan sembako. Begitu seterusnya hampir di setiap periode pergantian musim buah berlaku demikian.

Kondisi ekonomi para pedagang Mlijo ini relatif stagnan, hal ini ditunjukkan dengan lamanya mereka bekerja sebagai pedagang Mlijo, serta minimnya variasi strategi yang mereka jalankan untuk memenuhi kebutuhan hidup sehari-hari. Dalam hal ini mengindikasikan bahwa kurang adanya peningkatan yang signifikan pada kondisi perekonomian keluarga para pedagang Mlijo tersebut. Dalam strategi pemasaran barang dagangan, para pedagang Mlijo biasanya disamping memiliki aktivitas memasarkan barang-barang dagangannya, ada juga yang berupaya untuk memproduksi jenis dagangannya sendiri. Mereka yang memproduksi biasanya adalah pedagang-pedagang yang menjual makanan ringan seperti gorengan, keripik, peyek, dan kue-kue lainnya.

Pedagang Mlijo biasanya berhubungan langsung dengan konsumen atau pembeli. Mereka biasanya menawarkan barang dagangannya dengan harga yang lebih tinggi dibanding dengan harga yang ada di kios-kios atau dipasar tradisional. Walaupun demikian, tak jarang pembeli menawar harga yang lebih rendah lagi dari harga yang ditawarkan oleh pedagang Mlijo. Pada perdagangan mlijo, kegiatan tawar-menawar harga antara penjual dan pembeli merupakan suatu peristiwa yang biasa. Pedagang mlijo ingin mendapatkan laba yang besar dari harga yang ditawarkannya, sedangkan pembeli ingin mendapatkan harga yang murah.

Menurut (Yusuf, 2019) menjelaskan bahwa strategi yang diterapkan pedagang ialah strategi aktif, pasif, dan jaringan. (1) Strategi aktif, pada strategi ini pedagang lebih memanfaatkan sumber daya keluarga dan mengeluarkan segala pontensi yang dimilikinya. Seperti dengan menggunakan kreativitasnya dan mencari pelanggan tetap. (2) Startegi pasif, pada strategi ini pedagang lebih meminimalisir pengeluaran dan selektif memilih barang. Penghasilan yang terkadang tidak menentu membuat para pedagang jadi lebih berhemat agar segala kebutuhan dapat tercukupi. (3) Strategi jaringan, pada strategi ini para pedagang megutamakan meminta bantuan pada kerabat atau teman terdekat. Penelitian ini menyarankan agar Pemerintah Daerah Kabupaten Berau diharapkan bisa lebih tegas dalam memberikan surat izin berdagang diluar pasar Sanggam Adji Dilayas. 
Strategi para pedagang Mlijo ini dapat diketahui dari beberapa segi, diantaranya. Permodalan (Finance) Bagi pedagang Mlijo yang di kelurahan Cemorokandang, pengertian modal sendiri terbagi menjadi dua, yakni; modal dalam bentuk uang; modal dalam bentuk barang. Bagi para pedagang Mlijo, uang memiliki arti yang penting bagi kelanjutan kerja, atau going concer terutama sebagai modal untuk membeli barang dan memenuhi kebutuhan hidup sehari- hari. Modal dalam bentuk uang banyak dilakukan oleh para pedagang mlijo, namun dalam bentuk barang biasanya jarang dimiliki oleh para pedagang. Para pedagang yang memiliki modal dalam bentuk barang biasanya diperoleh setelah terlebih dahulu mendapat kepercayaan dari orang lain. Modal juga dapat bersumber dari hasil kerja sendiri (Yunus, 2011).

Aktifitas pedagang mlijo biasanya dilakukan mulai subuh sampai jam 12.00. Aktiftasnya berupa membeli macam macam kebutuhan pokok yang dibutuhkan masyarakat seperti sembako yang ada dipasar dan menjual Kembali sembako kepada masyarakat. Proses menjual kembali kepada masyarakat dilakukan dengan cara berkeliling dari kampung ke kampung. Dalam strategi kerja biasanya para pedagang Mlijo dituntut untuk memiliki strategi pada masing-masing pedagang terhadap pembeli. Strategi yang diterapkan oleh para pedagang Mlijo dalam menjajakan barangbarangnya sangat bervariasi. Biasanya ada yang pagi pagi jam 06.00 - sampai jam 12.00 pedagang Mlijo datang ke kampung kampung atau ke perumahan perumahan dengan membunyikan klakson sebagai pemberitahuan mereka telah datang. Ibu - ibu yang akan keluar rumah mendatangi pedagang Mlijo. Ibu ibu akan menanyakan harga barang yang akan dibeli. Terjadilah tawar menawar diantara pedangang dan pembeli. Jika sudah terjadi kesepakatan pedagang akan membungkus barang yang sudah dipilih pembeli. Pembeli akan membayar sesuai harga kesepakatan. Dalam tawar menawar biasanya pedagang akan lebih lunak pada pembeli karena menjadi langanan untuk penjualan selanjutnya. Pembeli akan memilih pedagang yang menjual harga lebih murah kalau kebutuhannya tidak mendesak. Dengan kata lain misalkan Mlijo yang datang pukul 06.00 harganya mahal maka pembeli akan menunggu Mlijo yang datang jam 10.00 jika kebutuhannya tidak mendesak.

Dalam berdagang, para pedagang terkait dalam strategi adaptasi. Adaptasi adalah suatu penyesuaian pribadi terhadap lingkungannya. Individu memiliki hubungan dengan lingkungannya yang menggiatkannya, merangsang perkembangannya, atau memberikan sesuatu yang ia perlukan. Penyesuaian diri yaitu mengubah diri sesuai dengan keadaan lingkungan atau mengubah lingkungan sesuai dengan keadaan diri. Menurut (Damsar, 2009) pada umumnya sebuah tindakan ekonomi terjadi dalam konteks hubungan sosial dengan orang lain. Oleh sebab itu, tindakan ekonomi dapat berlangsung dengan melibatkan kerjasama, kepercayaan dan jaringan. Maka dari itu, dalam strategi berjualan pedagang Mlijo, agar bisa bertahan harus diwujudkan dalam tindakan sosial yang dalam arti dilakukan oleh pedagang itu sendiri.

Perwujudan dari tindakan sosial yang dilakukan pedagang adalah dengan cara melakukan strategi. Strategi tersebut yaitu dalam bentuk kerja sama dengan petugas keamanan, membangun relasi dengan pembeli dan sesama pedagang agar tetap bertahan dalam berjualan. Seperti apa yang disampaikan oleh Bapak Muhammad sebagai berikut: "Di sini aku ya kerja samalah sama petugas yang menjaga perumahan, ya paling enggak ya permisi lah sama orang itu, tapi syukurnya orang itu disini ya pengertian sama sama kami dan tidak macam macam" (4/07/2014).

Adaptasi itu sendiri pada hakikatnya adalah suatu proses untuk memenuhi syarat-syarat dasar untuk tetap melangsungkan kehidupan. Syarat-syarat tersebut mencakup; Syarat dasar alamiah- biologi 
(manusia harus makan dan minum untuk menjaga kestabilan temperature tubuhnya agar tetap berfungsi dalam hubungan harmonis secara menyeluruh dengan organ- organ tubuh lainnya); Syarat kewajiban (manusia membutuhkan perasaan tenang yang jauh dari perasaan takut, keterpencilan, gelisah dan lain-lain); Syarat dasar sosial (manusia membutuhkan hubungan untuk dapat melangsungkan keturunan, untuk dapat mempertahankan diri dari serangan musuh, dan lain-lain). Dari batasan-batasan tersebut, dapat disimpulkan bahwa adaptasi merupakan proses penyesuaian. Penyesuaian diri individu, kelompok, maupun unit sosial terhadap norma- norma, proses perubahan, ataupun suatu kondisi yang diciptakan (Suparlan, 1993)

Kebutuhan hidup untuk mencapai kebutuhan pokok, sosial, dan pemupukan modal. Survival strategi tersebut ditempuh individu atau kelompok masyarakat, tergantung pada status sosial dan kondisi ekonominya. Strategi apa yang ditempuh juga berkaitan dengan kualitas sumber daya manusia dan lingkungan. Bagi kelompok masyarakat marginal, termasuk di dalamnya Pedagang mlijo, jenis strategi going concern. Hal ini menunjukkan bahwa; pedagang Mlijo memiliki daya tahan yang luar biasa ketika menghadapi tantangan dan persoalan hidup serta mereka mampu keluar dari kesulitan; mata pencaharian baru yang mereka tekuni juga tidak jauh dari usaha sebelumnya, yaitu di sekitar usaha ekonomi sektor informal. Sesuai dengan sistem orientasi nilai budaya (Kluckhohn dan F.L. Strodtbeck, 1961) sebagaimana dikembangkan oleh (Koentjaraningrat, 2009) hidup memang dipahami para pedagang mlijo sebagai sesuatu yang buruk, tetapi masih bisa diperbaiki kalau ingin tetap hidup.

\section{Hambatan yang dialami pedagang Mlijo}

Hambatan yang dialami pedagang mlijo kelurahan cemorokandang meliputi barang yang diperdagangkan, status perkawinan,tingkat pendidikan dan tingkat penghasilan. Dijelaskan oleh ibu Ani:"besar kecilnya barang yang disesuaikan kebutuhan pembeli, begitu juga dengan kualitas barangnya". Berdasarkan penjelasan tersebut berarti pedagang harus memilih barang yang dijual disesuaikan kepada kelompok kampung atau perumahan mana yang akan dituju.

Barang yang diperdagangkan menjadi hambatan jika barang tersebut tidak laku dijual. Barang yang tidak laku dijual biasanya digunakan atau dikonsumsi sendiri. Kalau barang itu sedikit jumlahnya tidak menjadi masalah tapi kalau jumlahnya besar akan menjadi masalah dan akan mengurangi modal

Setelah berumah tangga tentunya banyak kebutuhan dalam keluarga tersebut yang harus dipenuhi oleh suami dan istri. Apalagi jika suami dan istri sudah mempunyai anak tentunya beban tanggungan keluarga juga akan semakin besar. Yang dimaksud tanggungan keluarga disini adalah beban yang harus ditanggung oleh keluarga atau suami istri, dimana beban tersebut merupakan tanggung jawab yang timbul oleh karena hadirnya anak yang masih harus tergantung kepada orang tua. Beban keluarga merupakan tanggung jawab yang selalu dilaksanakan sebagai konsekuensi setelah memasuki masa berkeluarga atau berumah tangga. Tanggungan keluarga tersebut diwujudkan dalam bentuk biaya yang harus dikeluarkan untuk mencukupi kebutuhan pokok sehari-hari seperti kebutuhan akan makan, pakaian, kesehatan, biaya sekolah anak dan sebagainya.

Bagi komunitas pedagang Mlijo yang kesemuanya sudah berumah tangga, otomatis mereka juga mempunyai tanggungan keluarga sebagai konsekuensi hidup berumah tangga. Tanggungan keluarga merupakan salah satu pendorong mereka untuk bekerja mencari nafkah guna mencukupi kebutuhan hidup keluarganya. Dengan penghasilan mereka yang bekerja sebagai pedagang Mlijo 
dapat membantu suaminya dalam memenuhi kebutuhan hidup di keluarganya. Penuturan Ibu Ruroh , salah satu pedagang Mlijo yang akan memberikan sedikit gambaran tentang usaha para pedagang Mlijo perempuan dalam memenuhi beban tanggungan keluarga sebagai berikut: "Penghasilan bapak bekerja sebagai buruh tani , untuk mencukupi kebutuhan keluarga kadang tidak cukup. Karena itu aku berusaha seperti ini untuk mencukupi kebutuhan keluarga." (08/08/20)

Ibu yang mempunyai tiga orang anak yang menjadi tanggungan dua orang anak yang masih bersekolah di tingkat SMA, dan yang satunya masih di tingkat SMP. Penghasilan suami sebagai buruh tani tidak bisa mencukupi kebutuhan keluarga. Dari pernyataan tersebut tersirat adanya kerja keras dalam upaya memenuhi tanggung jawab terhadap keluarganya. Salah satu bentuk tanggungan keluarga seperti disebutkan di atas adalah pendidikan anak. Orang tua berkewajiban untuk menyekolahkan anak sampai batas kemampuannya. Demikian halnya para pedagang Mlijo tersebut. Keinginan menyekolahkan anak tercermin dari pernyataan beberapa responden yang menuturkan bahwa mereka menginginkan anak-anak. Mereka mendapatkan pendidikan yang baik untuk bekal masa depannya nanti (Purwanti, 2018).

Dari pernyataan itu dapat menunjukkan adanya perhatian yang tinggi terhadap pendidikan formal anak-anak mereka meskipun mereka umumnya memiliki tanggungan keluarga dan hanya bekerja sebagai pedagang Mlijo dengan tingkat pendidikan yang rendah. Dalam tingkat penghasilan sebagian besar komunitas pedagang Mlijo di kelurahan Cemorokandang memiliki tingkat penghasilan yang rendah. Keadaan tersebut dapat diketahui dari informasi yang diperoleh peneliti dari proses wawancara dengan responden yaitu para pedagang Mlijo yang telah memberikan keterangan tentang penghasilan mereka dalam berdagang. Penghasilan mereka tidaklah menentu tergantung dari banyak sedikitnya pembeli dan biasanya penghasilan mereka hanyalah cukup bahkan kurang untuk memenuhi kebutuhan pokok keluarga. Oleh karena itu sebagian besar tujuan dari mereka bekerja hanyalah untuk memperoleh penghasilan tambahan dari suaminya yang dapat digunakan untuk membantu suaminya dalam memenuhi kebutuhan keluarga (Yusuf, 2019).

Dijelaskan oleh pedagang Mlijo yaitu Ibu Ruroh, sebagai berikut: "Penghasilan ku berdagang Mlijo seperti ini ya tidak pasti, Tok, tergantung dengan barang yang diperdagangkan dan pembeli. Kalau pembeli membeli yang sama dengan barang yang diperdagangkan maka pengahasilan ku lumayan baik, tapi kalau barang yang ada tidak sesuai dengan yang diinginkan pembeli inginkan maka pengahasilan ku sedikit dan ada sembako yang tidak laku hari ini maka modalku akan berkurang. Misalkan dirata-rata penghasilan saya tiap harinya hanya sekitar Rp 50.000,00 sampai Rp100.000,00 cukup untuk makan dan sedikit menabung." (08/08/2020).

\section{KESIMPULAN}

Pedagang Mlijo sebagai salah satu sektor informal berfungsi sebagai sektor alternatif bagi para migran cukup memberikan sumbangan bagi pembangunan perkotaan. Selain membuka kesempatan kerja, kegiatan tersebut juga dapat meningkatkan pendapatan bagi masyarakat kota. Pedagang Mlijo yang berjualan di kelurahan Cemorokandang Kecamatan Kedungkandang Kota Malang mempunyai going concern yang bervariasi, diantaranya adalah going concern usaha dan going concern perekonomian keluarga, diantaranya dengan pengelolaan keuangan keluarga dengan memprioritaskan kebutuhan yang penting serta mengelola agar pengeluaran tidak melebihi pemasukan, pendistribusian alokasi keuangan untuk pendidikan, makan sehari-hari dan lainnya, melalui pinjaman, ada pula dengan menabung. 
Kondisi ini ditemukan pada pedagang Mlijo yang ada di Kelurahan Cemorokandang Kecamatan Kedungkandang Kota Malang relative stagnan, hal ini ditunjukkan dengan lamanya mereka bekerja sebagai pedagang Mlijo , serta sedikitnya variasi strategi yang mereka jalankan untuk memenuhi kebutuhan hidup sehari-hari. Dalam hal ini mengindikasikan bahwa kurang adanya peningkatan yangsignifikan pada kondisi perekonomian keluarga para pedagang Mlijo tersebut.

Pelaku sektor informal di kelurahan Cemorokandang dengan berbagai profesi disebabkan karena adanya keterbatasan dalam aspek ekonomi keluarga sebagai faktor utama yang mendorong mereka memilih sektor informal menjadi lahan basah peruntungan ekonomi bagi mereka untuk bisa memenuhi kebutuhannya, dan bertahan hidup. Selain itu faktor lain yang menyebabkan seseorang menjadi pedagang Mlijo adalah faktor usia kerja, tidak adanya pendidikan yang lebih memadai dan tidak adanya pekerjaan lain. Untuk menjaga going concern para pelaku sektor informal ada berbagai cara yang ditempuhnya. Modal usaha menjadi salah satu faktor penentu kelangsungan usaha pedagang Mlijo strategi lokasi, pendapatan /keuntungan, kiat berjualan, waktu berjualan dan semangat pentang menyerah.

Berdasarkan filosofi jawa terdapat beberapa filosofi perdagangan yang mengarah pada syairah yakni, sikap pasrah dengan rezeki karena sang maha pencipta tidak akan tidur, sedikit-sedikit yang terpenting jualan tetap jalan, dan orang pintar akan kalah dengan orang yang beruntung. Keberhasilan going concern dalam usaha dan perekonomian keluarga tidak lepas dari etnis madura dan jawa. Etnis madura terkenal dengan sifat wirausahanya yang sangat ulet, rajin dan pekerja keras. Etnis Jawa adalah memiliki etos kerja yang kuat, memprioritaskan keakraban, menghindari konflik, menerima segala sesuatu dengan tulus, dan juga memberi upaya maksimal dalam melakukan pekerjaan.

\section{SARAN}

Saran bagi pembuat kebijakan ialah untuk membuat kelonggaran terkait modal yang digunakan para pelaku Mlijo dan adanya wadah bagi pelaku pedagang Mlijo agar kerja mereka dapat terorganisir dengan baik. Bagi peneliti selanjutnya untuk menambahkan pembahasan fenomena yang signifikan bagi pelaku Mlijo dan penambahan teori terkait going concern.

\section{Daftar Pustaka}

12SPAP, PSA 30 SA341.1. (n.d.). 12SPAP, PSA 30 SA341.1.

Ginting, S., \& Tarihoran, A. (2017). Faktor-faktor yang mempengaruhi perilaku faktor-faktor yang mempengaruhi perilaku. Jurnal Wira Ekonomi Mikroskil, 7, 12.

Irwan. (2015). Strategi Bertahan Hidup Perempuan Penjual Buah-Buahan (Studi Perempuan di Pasar Raya Padang Kecamatan Padang Barat Kota Padang Propinsi Sumatera Barat). Humanus, Vol. XIV N.

Paranoan, N., Julianty, J., Sipi, A., Paranoan, A., \& Eny, N. (2021). Going Concern of Sambu Barumbun Metaphor in Mamasa Culture, West Sulawesi Indonesia. https://doi.org/10.4108/eai.4-112020.2304622

Purba, M. . (2009). Asumsi Going Concern (Suatu Tinjauan Terhadap Dampak Krisis Keuangan atas Opini Audit dan Laporan Keuangan) (ke-1). Graha ilmu.

Purwanti, T. (2018). Strategi Bertahan (Suvival Strategy) Pedagang Awul-Awul di Kecamatan Ungaran Kabupaten Semarang. Jurnal Universitas Negeri Semarang: Semarang.

Yunus, A. I. (2011). Potret Kehidupan Sosial Ekonomi Pedagang Kaki Lima di Kota Makassar (Kasus Penjual Pisang Epe' di Pantai Losari). Jurnal Sosiologi Fakultas Ilmu Sosial Dan Ilmu Politik Universitas Hasanuddin.

Yusuf, I. (2019). Strategi bertahan hidup pedagang pasar sanggam adji dilayas kabupaten berau. EJournal Sosiatri-Sosiologi, 7 (2): 195. 